\title{
Optimization study of cold storage warehouses using LNG cold energy
}

\author{
Danbee Han \\ Department of Environment-Energy, Suwon University of Suwon, \\ Hwaseong-si, Geonggi-do, 18323, Korea \\ Youngsoon Baek $\uparrow$ \\ Department of Environment-Energy, Suwon University of Suwon, \\ Hwaseong-si, Geonggi-do, 18323, Korea \\ Kyuin Yeom \\ Department of Environment-Energy, Suwon University of Suwon, \\ Hwaseong-si, Geonggi-do, 18323, Korea \\ Wooksang Cho \\ Department of Environment-Energy, Suwon University of Suwon, \\ Hwaseong-si, Geonggi-do, 18323, Korea \\ Jaerin Shin \\ EUGENE Super Freeze Co. Institute of Technology, \\ Yongin-si, Geonggi-do, 16827, Korea
}

\begin{abstract}
When liquefied natural gas (LNG) is vaporized to form natural gas for industrial and household consumption, a tremendous amount of cold energy is transferred from LNG to seawater as a part of the phase-change process. This heat exchange loop is not only a waste of cold energy, but causes thermal pollution to coastal fishery areas by dumping the cold energy into the sea. This project describes an innovative new design for reclaiming cold energy for use by cold storage warehouses (operating in the -35 to $62^{\circ} \mathrm{C}$ range). Conventionally, warehouse cooling is done by mechanical refrigeration systems that consume large amounts of electricity for the maintenance of low temperatures. Here, a closed loop LNG heat exchange system was designed (by simulator) to replace mechanical or vapor-compression refrigeration systems. The software PRO II with PROVISION V9.4 was used to simulate LNG cold energy, gas re-liquefaction, and the vaporized process under various conditions. The effects on sensible and latent heats from changes to the LNG supply pressure have been investigated, as well as an examination of the optimum operating conditions for LNG refrigerated warehouses.
\end{abstract}

key words - LNG, Cold energy, Refrigeration, Modeling, Refrigeration warehouse, Cold heat,

Simulation

\section{INTRODUCTION}

Liquefied natural gas (LNG) is composed of methane, ethane, propane, butane, and other components. LNG is obtained by removing nitrogen, carbon dioxide, and other impurities from natural gas, and then liquefying it via a low-temperature, high-pressure treatment facility (at an overseas gas field) to ensure convenient transport. Its storage density is approximately 430-470 
$\mathrm{kg} / \mathrm{m} 3$ (which is greater than 625 times that of the normal-state gas) with a low temperature of approximately $-162^{\circ} \mathrm{C}(1)$. In other words, LNG is a cryogenic liquid.

The Korea Gas Corporation imports LNG from overseas gas fields, where it's unloaded from LNG carriers and stored in tanks at LNG receiving terminals in Incheon, Pyeongtaek, Tongyeong, and Samcheok. Before being supplied to domestic consumers, LNG is treated by heat exchange with seawater via an open rack vaporizer (ORV). Cold energy of approximately $830-860 \mathrm{~kJ} / \mathrm{kg}$ is lost during this heat exchange, thereby removing $-162^{\circ} \mathrm{C}$ by vaporization (2). It's then sent in gaseous form (approximately $70 \mathrm{~atm}$ ) to regional supply bases, where its pressure is lowered to $20 \mathrm{~atm}$. Finally, it's sent to a local branch of the city gas company, where the pressure is further reduced to less than $1 \mathrm{~atm}$ for provision to households.

A huge amount of cold energy is dumped as pollution into the air and sea by this paradigm (3). There are existing cold storage warehouses that use LNG cold energy; such as the facility in Fukuoka, Japan (run by western gas engineering, capacity 27,600 tons) which uses 5 ton/hour of western gas, and the warehouse operated by Nippon Cryogenic Inc. in Yokohama with a capacity of 33,260 tons (4).

However, this is not the case for South Korea. The annual LNG consumption by the Republic of Korea (ROK) is approximately 38 million tons (as of 2013), corresponding to $7.6 \times 1012 \mathrm{kcal}$ (based on $200 \mathrm{kcal} / \mathrm{kg}$ ). As of 2014, 780 electric cold storage warehouses were being operated within Korea, and that number is increasing. Accordingly, the LNG cold system of Korea is estimated to utilize cold energy as high as $3.3 \times 1012 \mathrm{kcal}$ per year.

We expect that the core technology developed in this research will not only replace conventional electric energy used for cold storage warehouses (operating below $-100^{\circ} \mathrm{C}$ ) through the utilization of LNG cold energy, but it will also reduce $50-70 \%$ of the operating power costs, greatly facilitating the distribution industry. This is an important development because the production of natural gas (NG) for fuel by nearby processing plants (after the cold energy has been extracted) could greatly contribute to $\mathrm{CO}_{2}$ reduction and green energy growth.

Table -1 The Manufacture of Liquid N2, Oz, and Ar from Air using Cold Energy of LNG (4).

\begin{tabular}{|c|c|c|c|c|}
\hline \multirow{2}{*}{ Company } & \multirow{2}{*}{$\begin{array}{c}\text { Amount of LNG } \\
(\mathrm{t} / \mathrm{h})\end{array}$} & \multicolumn{3}{|c|}{ Capacity $(\mathrm{x} 1,000 \mathrm{Nm}$ 3/h) } \\
\cline { 3 - 5 } & & Liquid N2 & Liquid O2 & Liquid Ar \\
\hline Tokyo Liquid Nitrogen & 54 & 13.5 & 6.5 & 0.25 \\
\hline Tokyo Liquid Oxygen & 48 & 25 & 6 & 0.38 \\
\hline Central Liquid Oxygen & 52 & 10 & 5 & 0.1 \\
\hline Cold Air Product & 40 & 7.5 & 7.5 & 0.2 \\
\hline Nippon Air Gas & - & 3.5 & 3.5 & 0.07 \\
\hline European Cold Energy & 15 & 3.5 & 3.5 & 0.08 \\
\hline Clear Air & 50 & 15 & 6.5 & 0.4 \\
\hline Hydro Edge & - & 12 & 4 & 0.15 \\
\hline
\end{tabular}

In our research, conventional electric cooling systems were remodeled to use LNG cold energy. Various processing conditions, such as the amount of natural gas utilized for fuel and the type of refrigerant, were applied to the simulation in order to analyze the effectiveness of LNG cold energy. This study also proposes optimal conditions for the utilization of LNG cold energy 
via an analysis of changes to the sensible and latent heats resulting from LNG various supply pressures.



1. LNG storage tank 2. Low pressure LNG pump 3. BOG compressor 4. BOG reliquefier

5. high pressure LNG pump 6. Sea water vaporizer 7. Sea water Pump

Figure 1. The Process Facility of an LNG Receiving Terminal.

\section{II . MODELING AND SIMULATION OF THE LNG COLD SYSTEM}

Fig. 2 shows the modeled system using LNG cold energy as the cryogenic replacement for conventional electrically run cold storage facilities. Here, LNG cold energy is heat-exchanged with a refrigerant at the freezing heat exchanger ( $\mathrm{S} / \mathrm{F}$ class) and the refrigeration heat exchanger (F class), and then supplied to a warehouse. The $1,700 \mathrm{~kg} / \mathrm{h}$ of $\mathrm{LNG}$ passing through the heat exchanger becomes natural gas with a temperature greater than $5^{\circ} \mathrm{C}$, and is then sent to city gas pipelines or used within fuel cells. The $300 \mathrm{~kg} / \mathrm{h}$ of natural gas not used as fuel is then reliquefied and recirculated. LNG is supplied at a flow rate of $2,000 \mathrm{~kg} / \mathrm{h}$ at $-147^{\circ} \mathrm{C}$ and $10 \mathrm{~atm}$. The refrigerant used for heat exchange with LNG is R407C. The system was analyzed at 10, 30, 50 , and $70 \mathrm{~atm}$ to determine the influence of LNG supply pressure on the amount of LNG cold energy $(5,6)$. The effect of the refrigerant on the amount of LNG cold energy was analyzed by means of propane and $\mathrm{CO} 2$.

Table -2 The Components of various LNG.

\begin{tabular}{|c|c|c|c|}
\hline Component & Lean(\%) & Rich(\%) & Typical(\%) \\
\hline Nitrogen & 0.00 & 0.00 & 0.32 \\
\hline Methane & 96.74 & 85.12 & 90.0 \\
\hline Ethane & 1.89 & 8.63 & 6.26 \\
\hline Propane & 0.68 & 4.13 & 2.3 \\
\hline i-Butane & 0.34 & 1.10 & 0.63 \\
\hline n-Butane & 0.34 & 0.90 & 0.49 \\
\hline i-Pentane & 0.01 & 0.10 & 0.00 \\
\hline n-Pentane & 0.00 & 0.01 & 0.00 \\
\hline
\end{tabular}




\begin{tabular}{|l|l|l|l|}
\hline Total (\%) & 100 & 100 & 100 \\
\hline
\end{tabular}

Table 3 shows the analysis of cold energy and supply energy requirements for the liquefier and vaporizer, according to vapor fraction. LNG entered the heat exchanger at $-147^{\circ} \mathrm{C}, 10 \mathrm{~atm}$, and $2,000 \mathrm{~kg} / \mathrm{h}$. It came out at $-54^{\circ} \mathrm{C}$ and $10 \mathrm{~atm}$. It was assumed that the temperature of the NG increased to $5^{\circ} \mathrm{C}$ at the heater for delivery to fuel cells or city gas pipelines. $50 \%$ of the cold energy acquired (from heat exchangers 1 and 2, and the refrigerant R407C) was simulated as circulating through the cooling warehouse under the same conditions (Table 4). The variation in flow rates of refrigerant, according to its type, was also analyzed using the same inlet and outlet temperatures as the warehouse (also seen in Table 4). Fig. 2 shows the results of the simulation conducted.

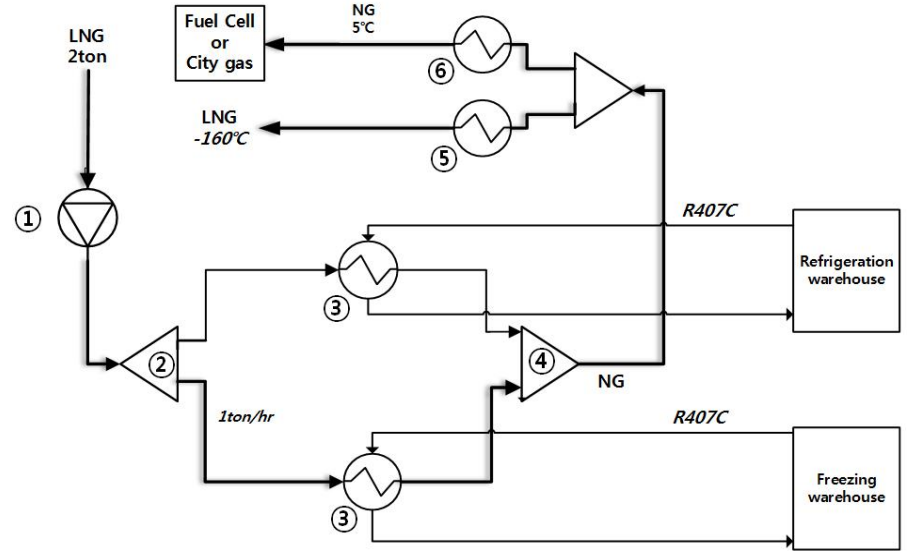

1. Pump 2. Splitter 3. LNG Heat exchanger 4. Mixer 5. Re-liquefaction 6. Heater

Figure 2. Modeling of cold storage Warehouse using Cold Energy of LNG

Table -3 Vapor fraction vs. Cold energy amount.

\begin{tabular}{|c|c|c|}
\hline $\begin{array}{c}\text { Vapor fraction } \\
\text { (Utilization of latent heat) }\end{array}$ & $\begin{array}{c}\text { Vapor(NG) } \\
\text { Amount(kg/h) }\end{array}$ & $\begin{array}{c}\text { Liquid(LNG) } \\
\text { Amount(kg/h) }\end{array}$ \\
\hline 0 & 0 & 2,000 \\
\hline 0.2 & 400 & 1,600 \\
\hline 0.4 & 800 & 1,200 \\
\hline 0.6 & 1,200 & 800 \\
\hline 0.8 & 1,600 & 400 \\
\hline 1.0 & 2,000 & 0 \\
\hline
\end{tabular}

Table -4 Conditions of various Refrigerants.

\begin{tabular}{|c|c|c|c|c|c|c|}
\hline \multirow{3}{*}{$\begin{array}{c}\text { Type of } \\
\text { refrigerant }\end{array}$} & \multicolumn{3}{|c|}{ Freezing (S/F class) } & \multicolumn{3}{c|}{ Refrigeration (F class) } \\
\cline { 2 - 7 } & $\begin{array}{c}\text { Pressure } \\
(\mathrm{atm})\end{array}$ & $\begin{array}{c}\mathrm{IN} \\
\left({ }^{\circ} \mathrm{C}\right)\end{array}$ & $\begin{array}{c}\text { OUT } \\
\left({ }^{\circ} \mathrm{C}\right)\end{array}$ & $\begin{array}{c}\text { Pressure } \\
(\mathrm{atm})\end{array}$ & $\begin{array}{c}\mathrm{IN} \\
\left({ }^{\circ} \mathrm{C}\right)\end{array}$ & $\begin{array}{c}\text { OUT } \\
\left({ }^{\circ} \mathrm{C}\right)\end{array}$ \\
\hline
\end{tabular}




\begin{tabular}{|c|l|l|l|l|l|l|}
\hline R407C & 15 & -62 & -85 & 2.5 & -35 & -45 \\
\hline Propane & 15 & -62 & -85 & 2.5 & -35 & -45 \\
\hline CO2 & 15 & -62 & -85 & 5.1 & -57 & -67 \\
\hline
\end{tabular}

Table -3 The Cold Energy for Components of various LNG.



Figure 2. Simulation of Refrigeration Warehouse System using Cold Energy of LNG by PRO II simulator.

\section{III . SIMULATION RESULTS AND DISCUSSION}

3.1 Energy requirement of main units according the amount of natural gas utilization

As mentioned, the natural gas remaining after LNG cold energy utilization, was subsequently used for fuel cells or city gas. Gas not used for fuel is re-liquefied for recirculation. Fig. 4 illustrates the energy requirements of equipment (=liquefaction + heating) based on natural gas utilization for various system environments. The more natural gas used for fuel cells or city power, the less remained to be liquefied, and thus the less energy needed for liquefaction. However, as the temperature of the gas for fuel cells and domestic fuel should be $5^{\circ} \mathrm{C}$ or higher, the heater required more energy. The slope of the graph in Fig. 4 indicates that liquefaction needed 5.8 times the energy required for heating. Thus, when all the natural gas generated is used, the utilization of LNG cold energy is maximized. 


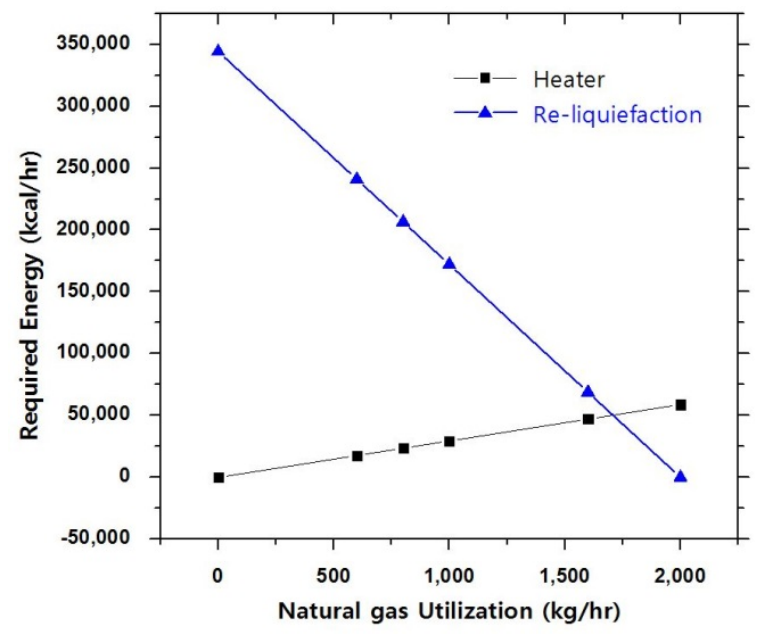

Figure 3. Energy of Main Units required with the amount of NG consumption.

\subsection{Variation of cold energy according the amount of natural gas utilization}

Fig. 5 shows the difference between input energy requirements and cold energy according to the amount of NG utilization (defined as $\Delta \mathrm{E}$ ). As can be seen, the more NG utilized, the greater $\Delta \mathrm{E}$, and the more cold energy that can be obtained from LNG. Therefore, if all of the NG is used, a maximum $\Delta \mathrm{E}$ of $264,000 \mathrm{kcal} / \mathrm{h}$ is obtained from cold energy.

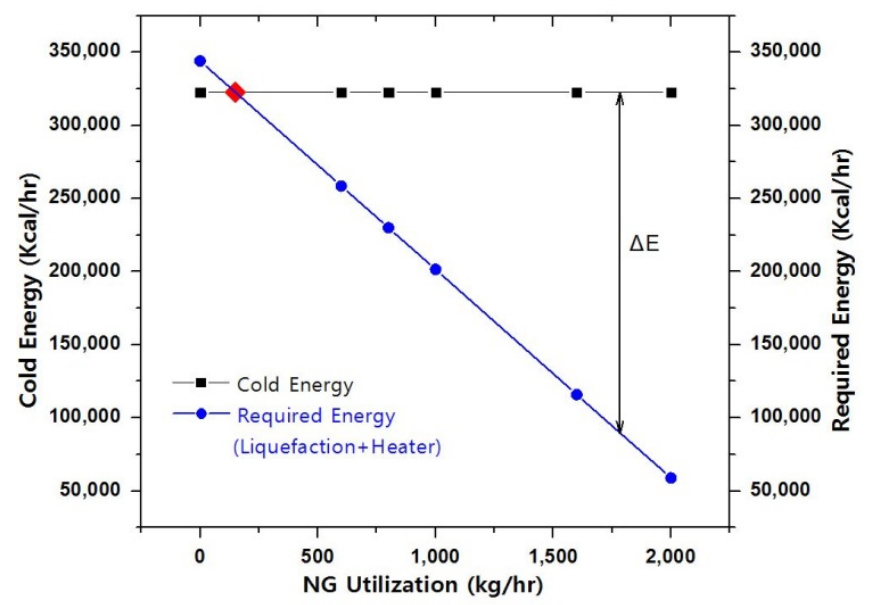

Figure 4. Energy of Main Units required with the amount of NG utilization. 


\subsection{Variation of cold energy according to utilization of latent heat of LNG}

Fig. 6 illustrates the amount of cold energy that can be obtained using the latent heat of LNG. As more latent heat is used, cold energy increases, but the input energy requirement decreases. If it's assumed that natural gas is used to $100 \%$, the amount of cold energy obtained (by using $77 \%$ of LNG as latent heat) is equivalent to the energy requirement. This means that all of the cold energy obtained is used for the system. Consequently, from the perspective of energy, both the sensible heat and latent heat of LNG need to be used at $10 \mathrm{~atm}$.

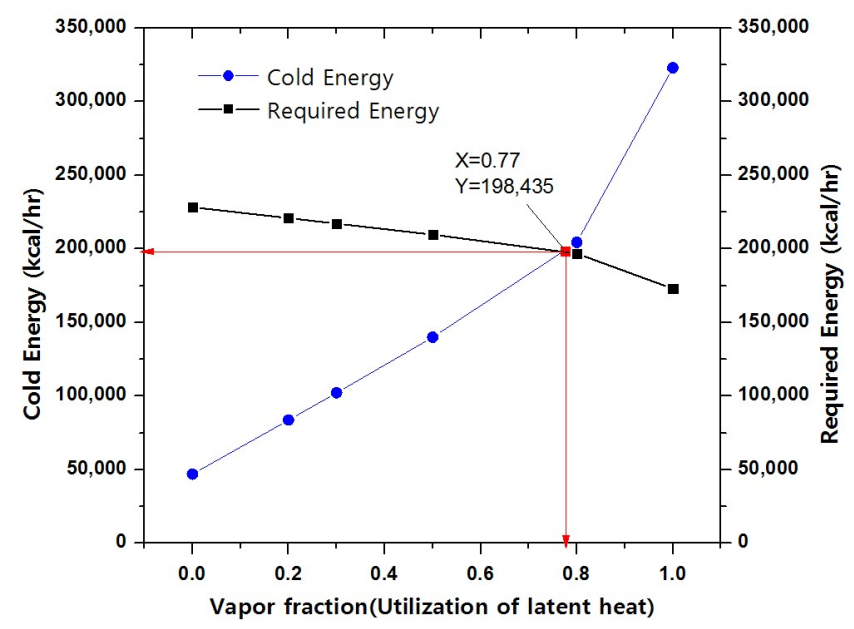

Figure 5. The Effect of ratio of Latent Energy Utilization on Cold Energy and required Energy for Liquefaction or Heating of NG.

3.4 Variation in flow rate of refrigerant according to its type

The refrigerant acquires cold energy from LNG in the heat exchanger, and transfers the cold energy to a cold storage warehouse. Table 6 shows the results of flow rates according to the type of refrigerant. Under the same conditions, a larger thermal capacity results in a lesser flow rate of refrigerant.

Table -4 The Change of Refrigerant flow rate with various Refrigerants.

\begin{tabular}{|c|c|c|c|}
\hline \multirow{2}{*}{$\begin{array}{c}\text { Type of } \\
\text { refrigerant }\end{array}$} & \multicolumn{2}{|c|}{ Flow rate (Kg/hour) } & \multirow{2}{*}{$\begin{array}{c}\text { Heat exchange } \\
\text { (Kcal/hour) }\end{array}$} \\
\cline { 2 - 3 } & $\mathrm{S} / \mathrm{F}$ & $\mathrm{F}$ & \multirow{2}{*}{161,000} \\
\hline R407C & 24,973 & 54,234 & \multirow{2}{*}{} \\
\hline Propane & 14,057 & 30,034 & \\
\hline $\mathrm{CO}_{2}$ & 16,770 & 37,109 & \\
\hline
\end{tabular}

With the same amount of heat exchange, R407C shows the largest flow rate, followed by $\mathrm{CO}_{2}$ and Propane. The power of the refrigerant pump increased by the same order. In cases where 
eco-friendly $\mathrm{CO}_{2}$ refrigerant is used, the flow rate needs to be higher pressure (versus propane) in order to maintain a liquid state. Otherwise an additional condenser is needed.

\subsection{Variation of cold energy according to supply pressure of LNG}

Fig. 7 displays the variations of sensible and latent energy according to the supply pressure of LNG, under the same temperature conditions. This is intended to identify the amount of available cold energy according to the supply pressure of LNG, and to determine the relationship between supply pressure and cold energy. As shown, when the supply pressure increases, the sensible heat also increases, but the latent heat decreases.

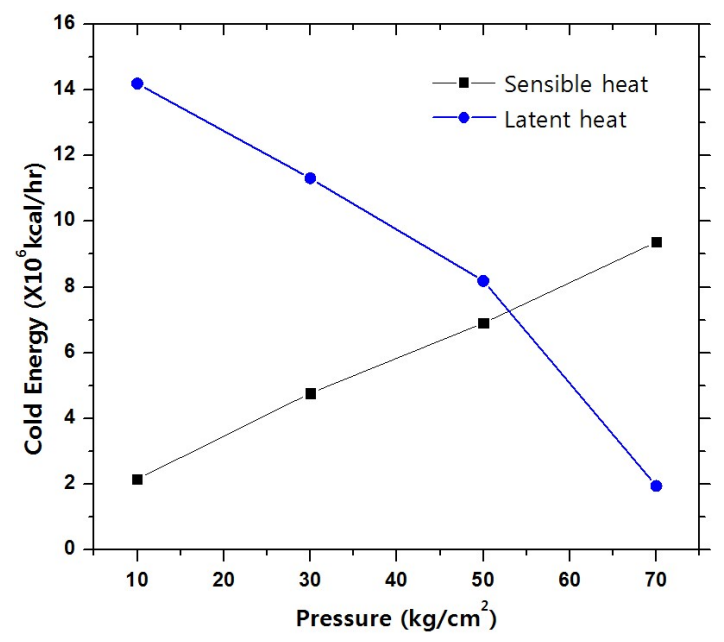

Figure 6. The Effect of Supply Pressure of LNG on Latent and Sensible Energy.

As alluded to previously, when the supply pressure is increased, the amount of latent energy decreased, as did the value of latent energy at a high pressure. This indicates there is no advantage for a high-pressure supply of LNG at an LNG receiving terminal. Fig. 8 shows various combinations of latent and sensible energy, as well as the latent energy according to supply pressure. As seen, the effect of the latent energy of LNG is almost insignificant at $70 \mathrm{~atm}$, which is the supply pressure of an LNG receiving terminal. 




Figure 7. The Effect of the Latent Energy Utilization of LNG on Cold Energy and the required Energy for Liquefaction or Heating of NG.

\section{IV.CONCLUSION}

The simulation results for cooling a cold storage warehouse using LNG cold energy were as follows

1) When the vaporized natural gas coming out of a heat exchanger is also used forfuel cells or city gas, the energy requirement for the vaporizer and re-liquefierdecreases, resulting in an increase of $\Delta \mathrm{E}$ (difference between cold energy and energy requirement). Thus, LNG cold energy can be maximally utilized.

2) When all remaining natural gas is used for fuel (after cold energy is removed from the LNG) about $264,000 \mathrm{kcal} / \mathrm{h}$ is available from an LNG cold energy of 2.0 tons. The more latent heat of LNG that is used, the larger amount of cold energy obtained. Thus, when all of the latent heat is used, the highest energy efficiency is achieved. When $80 \%$ of latent heat is used, $\Delta \mathrm{E}$ is $13,619 \mathrm{kcal} /$ hour.

3) With the same amount of heat exchange, R407C shows the largest flow rate followed by $\mathrm{CO} 2$ and Propane. The power of the refrigerant pump increased by the same order.

4) When the supply pressure of LNG increases, the latent heat and sensible heat approach the amount of cold energy. I.e. At 70 atm, the utilization of cold energy is similar. When the LNG supply pressure is 70 atm or above, using only sensible heat is advantageous due to the convenience of the post-treatment process.

\section{Acknowledgement}

This work is a product of the project, "Technology development of a freezing and refrigeration system using LNG cold energy $\left(-100^{\circ} \mathrm{C}\right.$ and above)". Our project is supported by the Energy Technology Development Business of the Korea Institute of Energy Technology Evaluation and Planning (KETEP), which is funded by the Ministry of Commerce, Industry, and Energy. 


\section{REFERENCES}

[1] S. Z. Tian, S. Chen, B Yang, Design of Liquefied Natural Gas Properties Calculation Software, Chemical Engineering of Oil and Gas. 43(2014)

[2] J. W. Wu, Y. M. Ma, S. Q. Chen, System Design and Analysis of Applying LNG Cold Energy to Refrigerated Warehouses, Journal of Jimei University(National Science), 15, 44-47(2010).

[3] Q. F. Liu, T. Lv, Application and Research of LNG Cold Energy, Guangdong Chemical Industry. 41,133134(2014).

[4] Promotion Project for Promotion of Global Warming Countermeasures, etc.", "Toward the Dissemination of Fuel Conversion Business to Southeast Asia by Export of LNG Subsea Transport Facilities Technology", Nomura Research Institute (2014)

[5] K.H Yang and S.C. Wu, Design Analysis of a Refrigerated Warehouse using LNG Cold Energy, Int'l J on Architectural Science,4(1) 14-23(2003)

[6] J.Lian and B.Xia, etc., Research on High Efficient Utilization of LNG Cold Energy, 4th Int'l Conference on Computer, Mechatronics, Control and Electronic Engineering(2015)

[7] D.B. Han, K. I. Yeom, J. R Shin Y.S. Baek, A study of simulation on the refrigerated warehouse system based on the cold energy of LNG using the PRO-II simulator", Trans. of the Korean Hydrogen and New Energy Society, Vol 28. , No. 4, (2017) 